\title{
Article \\ The Protective Role of Job Control/Autonomy on Mental Strain of Managers: A Cross-Sectional Study among Wittyfit's Users
}

\author{
Rémi Colin-Chevalier ${ }^{1, *(1)}$, Bruno Pereira ${ }^{2}\left(0\right.$, Amanda Clare Benson $^{3}\left(\mathbb{D}\right.$, Samuel Dewavrin $^{4}$, Thomas Cornet ${ }^{4}$ \\ and Frédéric Dutheil ${ }^{1}$ (1)
}

check for

updates

Citation: Colin-Chevalier, R.; Pereira,

B.; Benson, A.C.; Dewavrin, S.;

Cornet, T.; Dutheil, F. The Protective

Role of Job Control/Autonomy on

Mental Strain of Managers: A

Cross-Sectional Study among

Wittyfit's Users. Int. J. Environ. Res.

Public Health 2022, 19, 2153. https://

doi.org/10.3390/ijerph19042153

Academic Editor: Paul B. Tchounwou

Received: 20 December 2021

Accepted: 10 February 2022

Published: 14 February 2022

Publisher's Note: MDPI stays neutral with regard to jurisdictional claims in published maps and institutional affiliations.

Copyright: (c) 2022 by the authors. Licensee MDPI, Basel, Switzerland. This article is an open access article distributed under the terms and conditions of the Creative Commons Attribution (CC BY) license (https:// creativecommons.org/licenses/by/ $4.0 /)$.
1 CNRS, LaPSCo, Physiological and Psychosocial Stress, University Hospital of Clermont-Ferrand, Preventive and Occupational Medicine, Université Clermont Auvergne, Wittyfit, 63000 Clermont-Ferrand, France; fred_dutheil@yahoo.fr

2 Biostatistics Unit, Clinical Research and Innovation Direction, University Hospital of Clermont-Ferrand, 63000 Clermont-Ferrand, France; bpereira@chu-clermontferrand.fr

3 Department of Health and Biostatistics, Swinburne University of Technology, Hawthorn, VIC 3122, Australia; abenson@swin.edu.au

4 Wittyfit, 75000 Paris, France; samuel.dewavrin@wittyfit.com (S.D.); thomas.cornet@wittyfit.com (T.C.)

* Correspondence: r.colin6374@gmail.com

\begin{abstract}
Background: Karasek's Job Demand-Control-Support model is the gold standard to assess the perception of work; however, this model has been poorly studied among managers. We aimed to explore the perception of work (job demand, control, and support) in managers, and to quantify their risk of job strain (high job demand and low job control) and isostrain (job strain with low job support). Methods: We conducted a cross-sectional study on workers from various French companies using the Wittyfit software. Job demand, control, and support were evaluated by self-reported questionnaires, as well as sociodemographic data. Results: We included 9257 workers: 8488 employees (median age of 45 years, median seniority of 10 years, $39.4 \%$ women) and 769 managers (463 were more than 45 years old, 343 with more than 10 years of service, 33.3\% women). Managers had higher mean \pm SD levels than employees in job control $(79.2 \pm 14.9$ vs. $75.4 \pm 16.9)$ and job support ( $25.2 \pm 5.1$ vs. $24.0 \pm 6.1)$ $(p<0.001)$. Compared to employees, managers had a $37 \%$ decreased risk of job strain $(\mathrm{OR}=0.63$, $95 \%$ CI 0.52 to 0.77$)$ and a $47 \%$ decreased risk of isostrain (OR $=0.53,95 \%$ CI 0.40 to 0.69$)(p<0.001)$. Workers over age $45(\mathrm{OR}=1.26,95 \% \mathrm{CI} 1.14$ to $1.40, p<0.001)$ and women (OR $=1.12,95 \% \mathrm{CI} 1.01$ to 1. $25, p=0.03)$ were at greater risk of job strain. Furthermore, workers over age 45 (OR $=1.51,95 \% \mathrm{CI}$ 1.32 to $1.73, p<0.001)$, workers with over 10 years of service (OR $=1.35,95 \%$ CI 1.16 to $1.56, p<0.001)$, and women $(\mathrm{OR}=1.15,95 \% \mathrm{CI} 1.00$ to $1.31, p=0.04)$ were at greater risk of isostrain. Conclusions: Managers seem to have higher autonomy and greater social support and therefore are less at risk of job strain or isostrain than employees. Other factors such as age, seniority, and sex may influence this relationship. Trial Registration: Clinicaltrials.gov: NCT02596737.
\end{abstract}

Keywords: job demand; job control; job support; job strain; isostrain; manager; Karasek's model; work

\section{Introduction}

Karasek's Job Demand-Control-Support (JDCS) model [1-5] is a theory that helps to explain the relationship between job characteristics and the psychological well-being of workers. The model explains how the interaction of job demand (or psychological demand, e.g., work overload or role conflict), job control (or decision latitude, e.g., control over work pace or even workplace autonomy), and job support (or social support, e.g., emotional, physical, physiological, or practical assistance) can cause mental strain in individuals $[1,2,6,7]$. Job strain results from the interaction between high job demand and low job control, and isostrain is characterized by job strain with low social support. Job strain and isostrain have emerged as major public health problems with hazardous effects on workers [8-20]. 
Several factors such as age, seniority, or even sex are known to have an impact on job strain among workers [21-24]. To the best of our knowledge, there are few studies on the links between one's position within a company (manager or employee) and job strain or isostrain risk $[25,26]$, or studies which were carried out in one industry only, such as healthcare [15,27]. Despite managers' increased risk of stress [28] due to the multitude of tasks and responsibilities they face [29], their autonomy may overcome their job demand. As managers occupy a crucial role in a company, it therefore seems necessary to evaluate the impact of managerial status on the risk of mental strain, but also to identify other potential factors which may affect this relationship.

Thus, the main objective of our study was to evaluate the influence of job position (manager or employee) on the perception of work (job demand, job control, and job support) and mental strain (job strain and isostrain), particularly the putative protective role of job control among managers. The secondary objectives were to investigate other sociodemographic factors that may influence participant responses, using Karasek's model, and to quantify the impact of all these factors.

\section{Materials and Methods}

\subsection{Recruitment}

Wittyfit software is a web platform designed to promote and improve well-being in the workplace, implemented in various French industries that are clients of the Wittyfit company (Paris, France) [30]. Any worker wishing to participate in the Wittyfit study could register for free and access the eponymous application, which can be downloaded to a desktop computer or smartphone. Volunteer workers were asked to answer various questionnaires. They could anonymously provide personal information about their physical, mental, and work-related feelings in order to participate in the improvement of their own well-being. Managers and employees received personal and individualized feedback that could be used to implement a preventive strategy. The Wittyfit software was designed in partnership with the University Hospital of Clermont-Ferrand. All companies and workers using Wittyfit on a voluntary basis were included in the study. We limited the inclusion of data up to February 2020, prior to the COVID-19 pandemic.

\subsection{The Job Demand-Control-Support Model}

The three measurements of Karasek's model, namely, perceived job demand, job control, and job support, were assessed through the Wittyfit platform using visual analogical scales (VASs). VASs are widely used to assess perceived stress in workers [31-33]. Wittyfit's VASs are graded from 0 to 100, with 0 indicating a low level and 100 a high level. Therefore, job demand and job control were, respectively, assessed using the Wittyfit's VASs "workload" and "autonomy" from the "stress" questionnaire. Job support was assessed by the "ambiance" VAS from the "job satisfaction" questionnaire, designed to assess social support at work [30]. Then, the values were rescaled to match the true measurement scales. From a score of 0 to 100 , the levels of job demand, job control, and job support were rescaled to match the true measurement scales of the Karasek questionnaire. Thus, the VAS from 0 to 100 for job demand was converted into a score from 9 to 36, job control into a score from 24 to 96 , and job support into a score from 8 to 32. From this conversion, we were able to apply thresholds to our variables to transform them into qualitative variables to determine whether a worker was in a job strain or isostrain situation. Workers with more than 21 out of 36 in job demand and less than 70 out of 96 in job control were considered to be in a job strain situation. Job strain workers with less than 23 out of 32 in job support were considered to be in an isostrain situation. These values were chosen in accordance with the literature [6]. Throughout the duration of the study, when logging back into the platform, the workers could, if they wished, re-express how they felt in the different categories. The last scores entered by the user were used for the study. 


\subsection{Sociodemographic Charactertistics of Workers}

Sociodemographic characteristics considered were age, seniority, sex, position (manager or employee), and company they work for. A manager was defined as a worker with primary responsibility, having a leadership position over a group of workers, as opposed to an employee. This information was provided by Wittyfit's client companies and stored in the Wittyfit database. Thus, for each worker, age, seniority (in age groups), sex (male or female), and position (manager or employee) were known. Age was transformed from a multiclass variable into a binary variable indicating whether the worker was over or under 45 years old. In the same way, seniority was transformed into a binary variable indicating whether the worker had over or under 10 years of service.

\subsection{Statistical Analyses}

Quantitative data (job demand, control, and support), expressed by the mean \pm standard deviation (SD), were normalized using a "refit" method [34] and were compared between independent groups (by age, seniority, sex, and job position) with ANOVA. Qualitative data (job strain and isostrain) were described by a number of participants, and associated frequencies were compared between groups with the $\chi^{2}$ test. Then, multivariate analysis was conducted using linear or logistic mixed regressions depending on the outcome's nature (quantitative or qualitative, respectively) to determine variables associated with different Karasek model outcomes. The "company" effect was included as a random effect. Model assumptions (residual independence and normality, and variance homogeneity) were verified a posteriori. Multicollinearity of covariates was checked prior to analysis. Unless specified, all estimates were interpreted in terms of effect sizes (ESs) or standardized odds ratios (ORs) and 95\% confidence intervals (95\% CIs). ESs were interpreted according to Funder's rules [35]. Statistical analyses were performed with R (version 4.0.4) [36] in the RStudio (version 1.3.1056) platform. A p-value < 0.05 was considered statistically significant for all analyses.

\section{Results}

\subsection{Participants}

Data of 15,562 workers were collected between January 2018 and February 2020. We obtained complete data from 5656 men and 3601 women, i.e., 9257 workers, including 769 managers $(8.3 \%$ of workers) (Figure 1$)$.

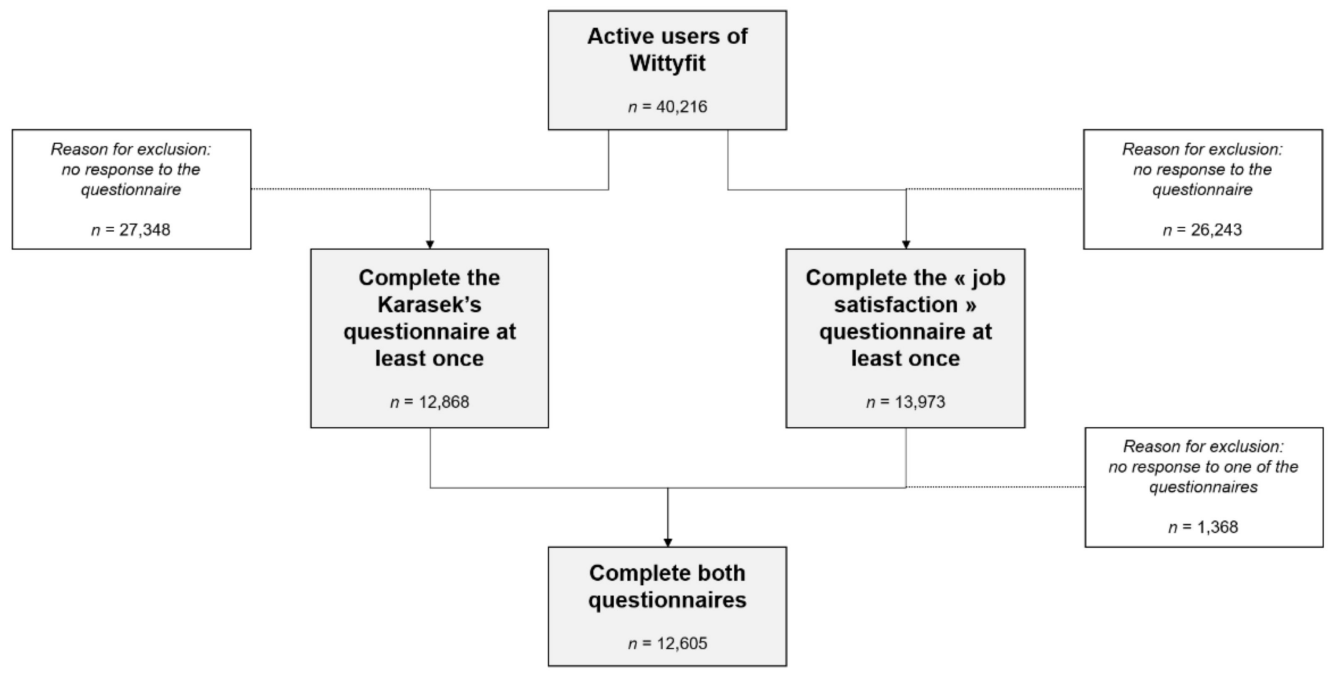

Figure 1. Flow chart of Wittyfit's users.

Table 1 shows the sociodemographic characteristics of workers by score obtained using Karasek's model. 
Table 1. Characteristics of workers according to their classification using Karasek's Job DemandControl-Support model (JDCS).

\begin{tabular}{|c|c|c|c|c|c|}
\hline \multirow{2}{*}{ Variable } & \multicolumn{4}{|c|}{ JDCS Model Groups } & \multirow{2}{*}{$p$-Value } \\
\hline & Active & High Strain & Low Strain & Passive & \\
\hline \multicolumn{6}{|c|}{ JDCS (mean \pm SD) } \\
\hline$n(\%)$ & $5537(59.8 \%)$ & $2235(24.1 \%)$ & $927(10.0 \%)$ & $558(6.0 \%)$ & \\
\hline Job demand & $29.3 \pm 4.2$ & $27.3 \pm 4.5$ & $15.9 \pm 3.4$ & $15.8 \pm 3.6$ & $<0.001$ \\
\hline Job control & $85.1 \pm 7.7$ & $55.3 \pm 11.2$ & $84.0 \pm 8.0$ & $50.5 \pm 13.6$ & $<0.001$ \\
\hline Job support & $25.2 \pm 5.6$ & $21.8 \pm 6.1$ & $25.2 \pm 5.9$ & $21.0 \pm 6.7$ & $<0.001$ \\
\hline \multicolumn{6}{|l|}{ Age (years), $n(\%)$} \\
\hline$<45$ & $2829(51.1 \%)$ & $1024(45.8 \%)$ & $523(56.4 \%)$ & $293(52.5 \%)$ & $<0.001$ \\
\hline$\geq 45$ & $2708(48.9 \%)$ & $1211(54.2 \%)$ & $404(43.6 \%)$ & $265(47.5 \%)$ & \\
\hline \multicolumn{6}{|c|}{ Seniority (years), $n(\%)$} \\
\hline$<10$ & $3229(58.3 \%)$ & $1238(55.4 \%)$ & $638(68.8 \%)$ & $369(66.1 \%)$ & $<0.001$ \\
\hline$\geq 10$ & $2308(41.7 \%)$ & $997(44.6 \%)$ & $289(31.2 \%)$ & $189(33.9 \%)$ & \\
\hline \multicolumn{6}{|l|}{ Sex, $n(\%)$} \\
\hline Male & $3349(60.4 \%)$ & $1302(58.3 \%)$ & $644(69.5 \%)$ & $364(65.2 \%)$ & $<0.001$ \\
\hline Female & $2191(39.6 \%)$ & $933(41.7 \%)$ & $283(30.5 \%)$ & $194(34.8 \%)$ & \\
\hline \multicolumn{6}{|l|}{ Position, $n(\%)$} \\
\hline Employee & $5041(91.0 \%)$ & $2097(93.8 \%)$ & $826(89.1 \%)$ & $524(93.8 \%)$ & $<0.001$ \\
\hline Manager & $91(9.0 \%)$ & $93.8(6.2 \%)$ & $101(10.9 \%)$ & $34(6.1 \%)$ & \\
\hline
\end{tabular}

Of the 9257 workers included in the study, 5537 (59.8\%) had an "active" job (high demand, high control) according to the Karasek model, 558 (6.0\%) a "passive" job (low demand, low control), 927 (10.0\%) a "low strain" job (low demand, high control), and 2235 (24.1\%) a "high strain" job and were in a job strain situation (high demand, low control). Further, among job strain workers, 1192 individuals (12.9\% of the total population) were in an isostrain situation.

3.2. Impact of Sociodemographic Characteristics of Workers on Responses to the JDCS Model 3.2.1. Job Demand, Control, and Support among Workers

On average, managers had significantly higher job control (79.2 \pm 14.9 vs. $75.4 \pm 16.9$, $p<0.001)$ and job support $(25.2 \pm 5.1$ vs. $24.0 \pm 6.1, p<0.001)$ than employees, but there was a non-significant difference in job demand (26.8 \pm 6.4 vs. $26.7 \pm 6.3, p=0.3$ ) (Figure 2). According to our results, both managers and employees using the Wittyfit software felt, on average, "active" at work (Figure 3).
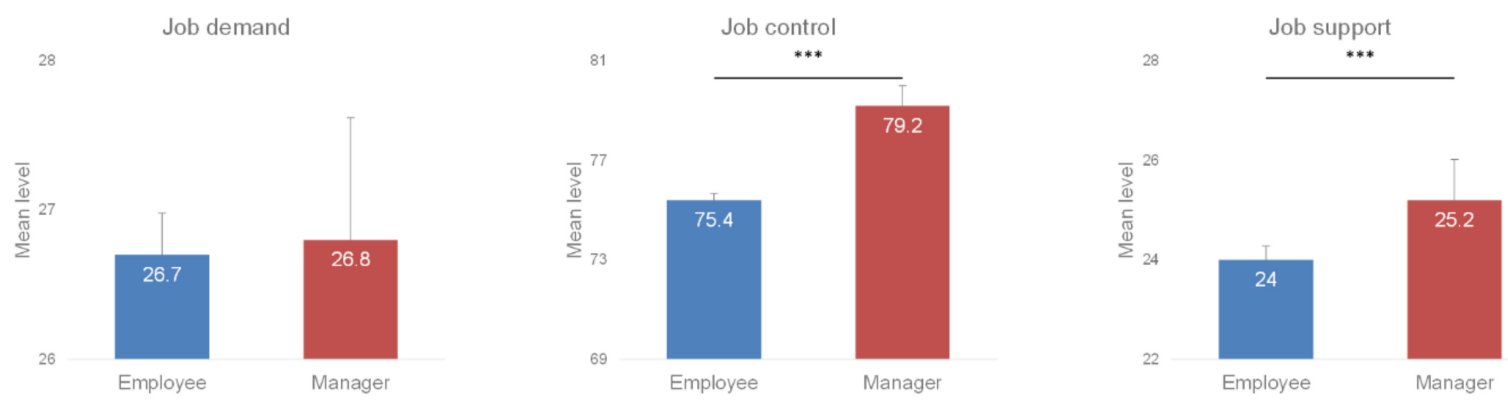

Figure 2. Job demand, job control, and job support by position. Legend: ${ }^{* * *} p<0.001$. 


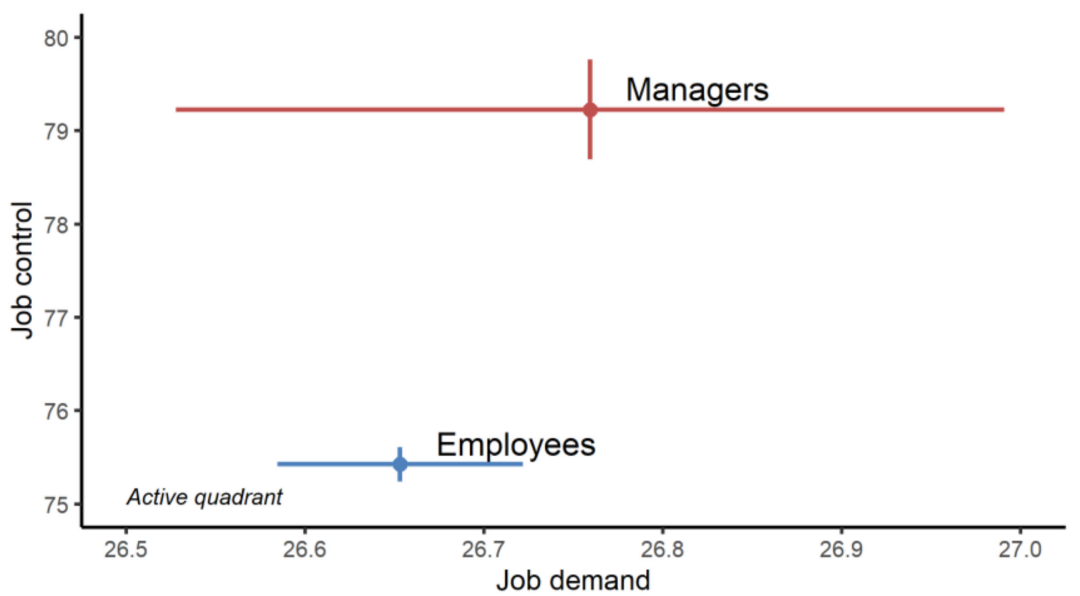

Figure 3. Karasek's Job Demand-Control-Support model. Point ranges are expressed as means and standard errors. Job demand varies from 9 to 36, job control from 24 to 96.

\subsubsection{Job Strain and Isostrain Prevalence by Job Position}

Managers had a lower risk of job strain ( $\mathrm{OR}=0.63,95 \% \mathrm{CI} 0.52$ to $0.77, p<0.001)$ and isostrain ( $\mathrm{OR}=0.53,95 \% \mathrm{CI} 0.40$ to $0.69, p<0.001)$ than employees. Thus, there was a lower prevalence of job strain $(17.9 \%$ of managers vs. $24.7 \%$ of employees, $p<0.001)$ and isostrain (8.1\% of managers vs. $13.3 \%$ of employees, $p<0.001$ ) among managers (Figure 4 ).

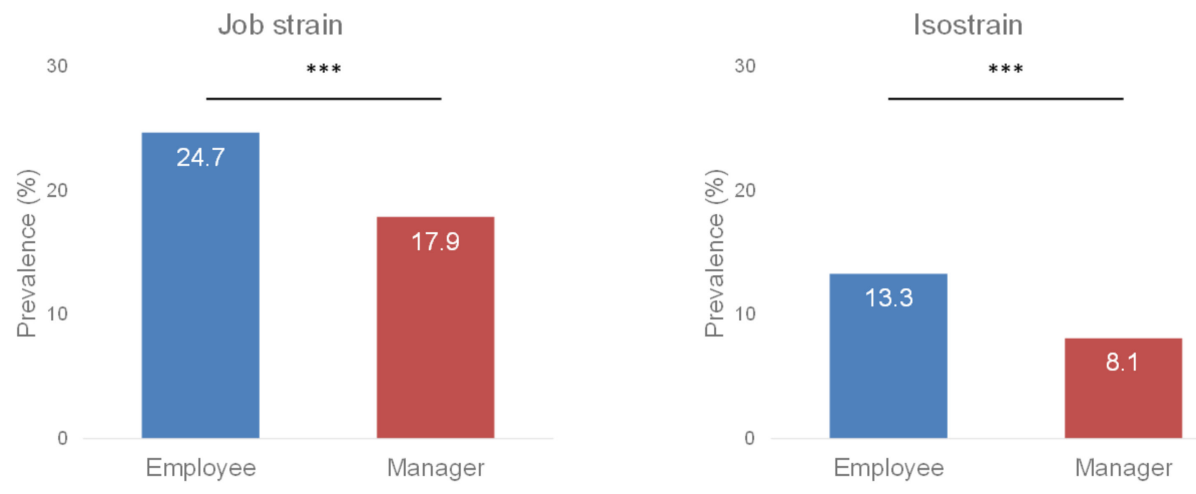

Figure 4. Prevalence of job strain and isostrain by job position. Legend: ${ }^{* * *} p<0.001$.

\subsubsection{Sociodemographic Factors of Karasek's Model}

Age emerged as a factor that influenced some dimensions of Karasek's model among all workers (both managers and employees). Indeed, workers over 45 had, on average, higher job demand ( $\mathrm{ES}=0.06,95 \% \mathrm{CI} 0.01$ to $0.10, p=0.009)$, lower job control $(\mathrm{ES}=-0.06$, $95 \% \mathrm{CI}-0.11$ to $-0.02, p=0.004)$, and lower job support $(\mathrm{ES}=-0.19,95 \% \mathrm{CI}-0.24$ to $-0.15, p<0.001)$. Moreover, similar to age, workers with over 10 years of seniority reported having higher job demand ( $\mathrm{ES}=-0.15,95 \% \mathrm{CI}-0.20$ to $-0.10, p=0.02)$ and less job support (ES $=-0.21,95 \% \mathrm{CI}-0.26$ to $-0.16, p<0.001$ ) (Figure 5 ).

Furthermore, women reported having higher job demand ( $E S=0.05,95 \%$ CI 0.01 to $0.09, p=0.02$ ) than men but lower job support $(\mathrm{ES}=-0.10,95 \% \mathrm{CI}-0.14$ to -0.06 , $p<0.001)$. Finally, our results show that the prevalence of job strain was higher among over- 45 workers $(\mathrm{OR}=1.26,95 \% \mathrm{CI} 1.14$ to $1.40, p<0.001)$ and women $(\mathrm{OR}=1.12,95 \%$ CI 1.01 to $1.25, p=0.03$ ). Likewise, the prevalence of isostrain was higher among over45 workers $(\mathrm{OR}=1.51,95 \% \mathrm{CI} 1.32$ to $1.73, p<0.001)$, workers with 10 or more years of service (OR $=1.35,95 \% \mathrm{CI} 1.16$ to $1.56, p<0.001)$, and women $(\mathrm{OR}=1.15,95 \% \mathrm{CI} 1.00$ to $1.31, p=0.04$ ) (Figure 6). 

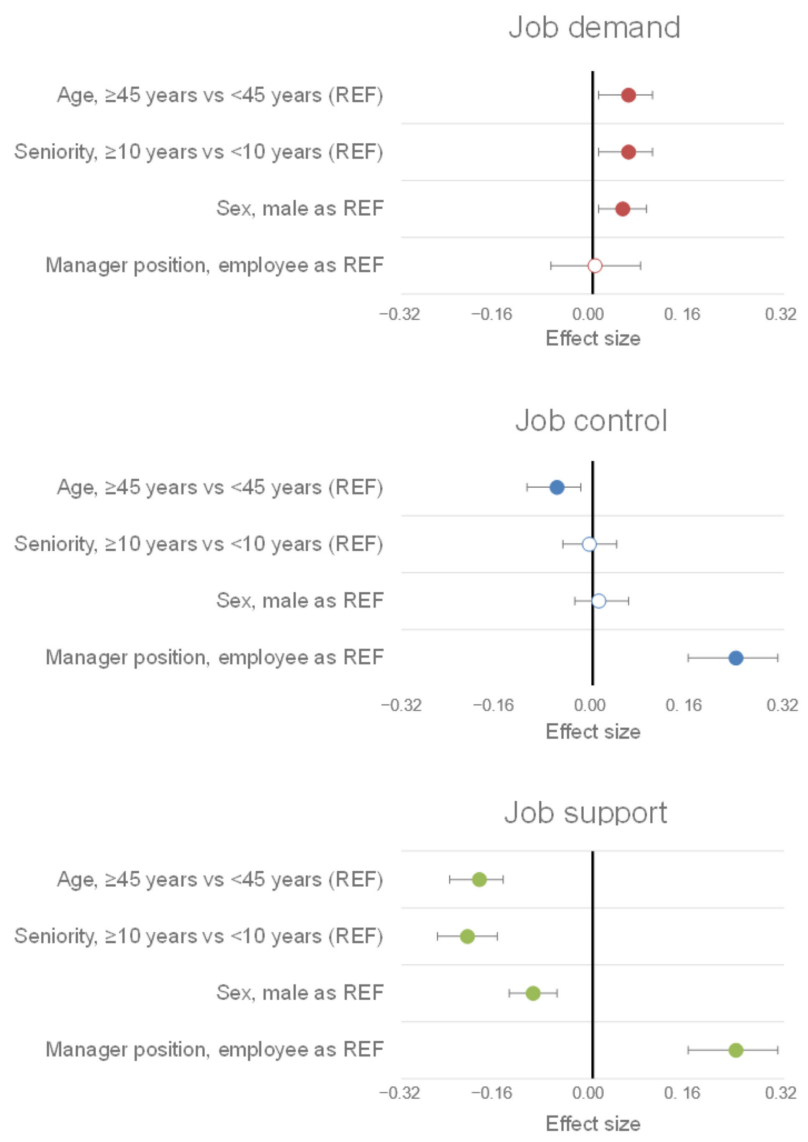

Figure 5. Sociodemographic factors of the Karasek model dimensions. A colored circle means that the measured effect is significant. The reference classes (REF) of the different parameters are the following: age: workers under 45; seniority: workers with less than 10 years of service; sex: male; job position: employee.

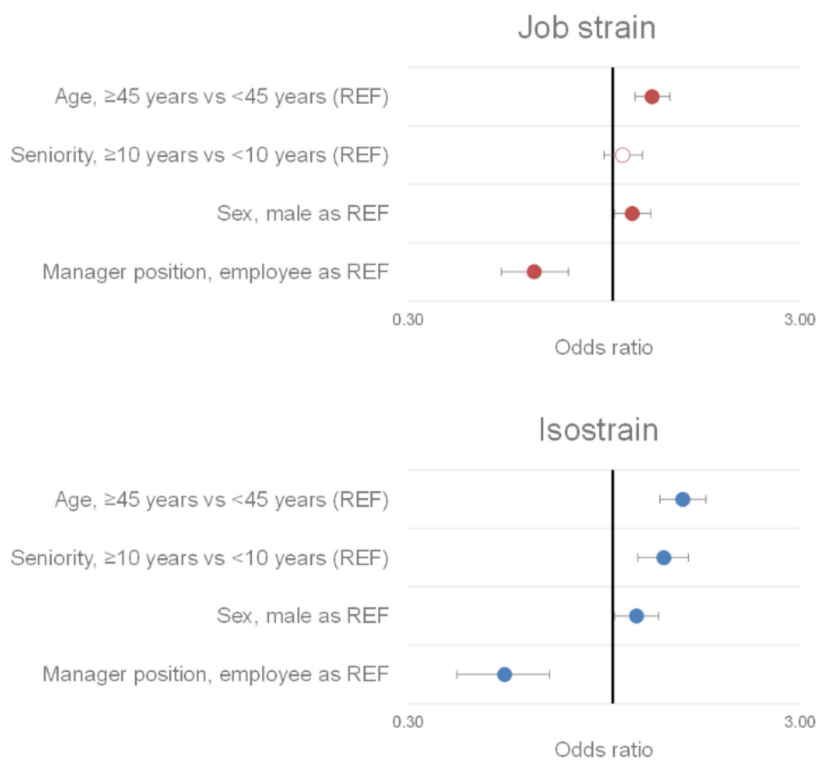

Figure 6. Sociodemographic factors of job strain and isostrain. A colored circle means that the measured effect is significant. The reference classes (REF) of the different parameters are the following: age: workers under 45; seniority: workers with under less than 10 years of service; sex: male; job position: employee. 


\section{Discussion}

The main results show that, due to higher job control and job support, managers were at less risk of job strain and isostrain than employees. However, other characteristics such as age, seniority, or sex were found to have an impact on the JDCS dimensions [5], sometimes protective, sometimes hazardous.

\subsection{The Managers and Karasek's Model}

Among workers who answered the JDCS questionnaire, we found that managers were less exposed to the risk of job strain and isostrain than employees. Indeed, only $17.9 \%$ of managers were in a job strain situation, compared to $24.7 \%$ of employees. Likewise, only $8.1 \%$ of managers were in an isostrain situation, compared to $13.3 \%$ of employees. In particular, the results highlight that the high levels of job control and job support perceived by the managers protect them from these risks. This suggests that the role of the manager, and more specifically the specificities of the manager's work, as opposed to that of the employee, acts as a protective factor against job strain and isostrain. These results confirm previous findings showing the impact of socioeconomic status on workers' type of job, on the one hand, and on the prevalence of job strain and isostrain, on the other, among workers, particularly the lower prevalence for workers with a higher socioeconomic position such as managers $[25,26,37]$.

We did not show a difference in job demand between managers and employees. This result may seem surprising, especially since studies have shown higher job demand for managers [38]. Nevertheless, in our study, the three outcomes measured relate to the employee's perception of his or her own activity. In particular, a manager is generally expected to take on management tasks in addition to their own, unlike an employee. However, since these additional tasks are an integral part of a manager's job, they may factor into the perceived workload scale. This could explain the absence of a significant difference between employees and managers in their perceived job demand. However, managers reported having slightly higher job control and job support than employees. The strong empowerment (described in the literature as a form of control or autonomy) of managers has been shown previously in nurses $[39,40]$, with a positive correlation between empowerment and positive work-related outcomes [39]. The difference in social support between managers and employees is coherent, as managers may receive support from their subordinates in addition to workers of the same or higher grade, improving the perception of their work [41]. Institutions should work to improve decision latitude and social support in the workplace. This should result in a consequent reduction in job strain and isostrain risks for workers, resulting in an improvement in their occupational well-being, especially for employees who are at greater risk.

\subsection{The Other Factors of Job Strain and Isostrain}

Sociodemographic factors may affect perceptions of work. In our study, we found a positive influence of age on job demand and a negative influence on job control and job support. This resulted in a higher risk of job strain and isostrain for people older than 45 years old. Previous studies have shown that, on the contrary, the risk of job strain seems to decrease with age [38] or has no effect [6]. Similarly, we found that seniority was positively associated with job demand and negatively associated with job support, resulting in a higher risk of isostrain for workers with more than 10 years of seniority. This suggests that, over the years, workers feel that the work they are asked to do becomes increasingly demanding, and that they lose the support from their colleagues or their management, thereby increasing their risk of strain.

According to our results, it seems that women perceived higher job demand than men while receiving less job support, which has previously been shown among managers [22]. Thus, women are slightly more at risk of job strain and isostrain than men, as already established in previous studies [24,38]. While the harmful effects of stress at work are well known among women [42], our study also shows that this is a population at risk. 
Our results confirm that personal factors can alter the perception of work. This reinforces the idea that the Karasek model should not be applied without considering the sociodemographic attributes of workers. Institutions should strive to ensure that older (and more senior) workers feel as regarded as younger workers. They must also be aware of potential differences in the perception of work between men and women, in order to take all the measures to enable their employees, regardless of their sex, to feel on an equal footing.

\subsection{Limitations}

We acknowledge some limitations in our study. Despite the fact several factors such as education or shift work are known to have an impact on job strain [24], they are not retrieved by Wittyfit. The use of self-reported responses to questionnaires could have led to over- or under-estimated values, which might lead to a measurement bias. Additionally, the use of a single VAS to assess each dimension of Karasek's model, instead of a multiitem questionnaire, may reinforce the idea of an affective bias. However, the quadrant classification of the JDCS model, based on historically studied thresholds, allowed us to obtain figures in agreement with the literature, with these values being very close to our first quartile $(\mathrm{Q} 1)$ and tercile $(\mathrm{T} 1)$ values (workload: $\mathrm{Q} 1=22.5, \mathrm{~T} 1=23.9$; autonomy: $\mathrm{Q} 1=65.8, \mathrm{~T} 1=73.7$; ambiance: $\mathrm{Q} 1=20.0, \mathrm{~T} 1=21.0$ ), often used as cut-offs to detect job strain and isostrain risk in various studies [43]. With this construct, we found that $24 \%$ of the population was in a job strain situation and $13.1 \%$ in an isostrain situation, in line with the literature $[9,11,24]$. Further, as an ever-expanding, real-world database, we can expect further investigations and comparisons of these results, in the future, with a larger dataset, even with repeated measurements and thus with more measurements per individual. Numerous companies were included in the study, but they only represented a small sample of possible business types. Nevertheless, the use of mixed models allowed us to take into account a "company" effect and to separately estimate the effects of sociodemographic characteristics. As Wittyfit's clients did not provide further details about their employees, such as their job, our sample might be non-representative of French workers. However, the use of the "Wittyfit" database allowed us to work with a large sample representative of various management positions [30], which was our main focus. These considerations allow us to assume the generalizability of our results.

\section{Conclusions}

Managers have a lower risk of job strain and isostrain. Indeed, they have higher levels of control and support at work than employees. Older workers and those with higher seniority may also be slightly more at risk of job strain. Irrespective of job position, acting on the main dimensions of Karasek's model (job demand, job control, and job support) at work can be beneficial in improving the well-being of workers. Thus, implementing strategies to improve, among other things, decision latitude and social support in the workplace could help companies reduce the risk of job strain and isostrain.

Author Contributions: Study design: F.D., S.D. and T.C.; study conduct: R.C.-C., F.D., B.P. and S.D.; data collection: F.D. and S.D.; data analysis: R.C.-C. and B.P.; data interpretation: R.C.-C., F.D. and B.P.; drafting manuscript: R.C.-C.; revising manuscript content: R.C.-C., F.D., B.P. and A.C.B.; approving final version of manuscript: all authors. R.C.-C., B.P., S.D. and F.D. take responsibility for the integrity of the data analysis. All authors have read and agreed to the published version of the manuscript.

Funding: This study received no external funding.

Institutional Review Board Statement: This study was approved by the National Commission for Data Protection and Liberties (CNIL), and the South-East VI ethics committee (clinicaltrials.gov identification number NCT02596737).

Informed Consent Statement: Informed consent was obtained from all subjects involved in the study. This information is set out in Wittyfit's terms and conditions of use. 
Data Availability Statement: Data from Wittyfit cannot be transmitted without the prior consent of the company's corporate clients, except to the University Hospital of Clermont-Ferrand, France, which may use the data for research purposes.

Acknowledgments: We express our sincere gratitude to all voluntary workers using Wittyfit, who participated in this study.

Conflicts of Interest: R.C.-C., S.D. and T.C. are employed by Wittyfit. The other authors declare that no competing interests exist (F.D. is responsible for the scientific accuracy of Wittyfit but is not paid by Wittyfit; as previously published, Wittyfit is a public-private partnership with the CHU Clermont-Ferrand).

\section{References}

1. Karasek, R.; Brisson, C.; Kawakami, N.; Houtman, I.; Bongers, P.; Amick, B. The Job Content Questionnaire (JCQ): An instrument for internationally comparative assessments of psychosocial job characteristics. J. Occup. Health Psychol. 1998, 3, $322-355$. [CrossRef] [PubMed]

2. Karasek, R.; Baker, D.; Marxer, F.; Ahlbom, A.; Theorell, T. Job decision latitude, job demands, and cardiovascular disease: A prospective study of Swedish men. Am. J. Public Health 1981, 71, 694-705. [CrossRef] [PubMed]

3. Karasek, R.A. Job Demands, Job Decision Latitude, and Mental Strain: Implications for Job Redesign. Adm. Sci. Q. 1979, 24, 285-308. [CrossRef]

4. Johnson, J.V.; Hall, E.M. Job strain, work place social support, and cardiovascular disease: A cross-sectional study of a random sample of the Swedish working population. Am. J. Public Health 1988, 78, 1336-1342. [CrossRef] [PubMed]

5. Karasek, R.; Theorell, T. Healthy Work: Stress, Productivity, and the Reconstruction of Working Life; Basic Books: New York, NY, USA, 1990.

6. Niedhammer, I.; Chastang, J.F.; Gendrey, L.; David, S.; Degioanni, S. Psychometric properties of the French version of Karasek's «Job Content Questionnaire» and its scales measuring psychological pressures, decisional latitude and social support: The results of the SUMER. Sante Publique 2006, 18, 413-427. [CrossRef]

7. Niedhammer, I.; Chastang, J.-F.; Levy, D.; David, S.; Degioanni, S.; Theorell, T. Study of the validity of a job-exposure matrix for psychosocial work factors: Results from the national French SUMER survey. Int. Arch. Occup. Environ. Health 2008, 82, 87-97. [CrossRef]

8. Collins, S.M.; Karasek, R.A.; Costas, K. Job strain and autonomic indices of cardiovascular disease risk. Am. J. Ind. Med. 2005, 48, 182-193. [CrossRef]

9. Rugulies, R.; Krause, N. Job strain, iso-strain, and the incidence of low back and neck injuries. A 7.5-year prospective study of San Francisco transit operators. Soc. Sci. Med. 2005, 61, 27-39. [CrossRef] [PubMed]

10. Bugajska, J.; Jędryka-Góral, A.; Widerszal-Bazyl, M.; Orłowska-Baranowska, E.; Sagan, A.; Michalak, J.M.; Zuzewicz, K.; Konarska, M. Job strain, overtime, life style, and cardiovascular risk in managers and physical workers. Int. J. Occup. Saf. Ergon. 2011, 17, 25-32. [CrossRef] [PubMed]

11. Kivimäki, M.; Nyberg, S.T.; Batty, G.D.; Fransson, E.I.; Heikkilä, K.; Alfredsson, L.; Bjorner, J.B.; Borritz, M.; Burr, H.; Casini, A.; et al. Job strain as a risk factor for coronary heart disease: A collaborative meta-analysis of individual participant data. Lancet 2012, 380, 1491-1497. [CrossRef]

12. Steptoe, A.; Kivimäki, M. Stress and cardiovascular disease. Nat. Rev. Cardiol. 2012, 9, 360-370. [CrossRef]

13. Landsbergis, P.A.; Dobson, M.; Koutsouras, G.; Schnall, P. Job strain and ambulatory blood pressure: A meta-znalysis and systematic review. Am. J. Public Health 2013, 103, e61-e71. [CrossRef]

14. Linton, S.J.; Kecklund, G.; Franklin, K.A.; Leissner, L.C.; Sivertsen, B.; Lindberg, E.; Svensson, A.C.; Hansson, S.O.; Sundin, Ö.; Hetta, J.; et al. The effect of the work environment on future sleep disturbances: A systematic review. Sleep Med. Rev. 2015, 23, 10-19. [CrossRef]

15. Wong, C.A.; Laschinger, H.K.S. The influence of frontline manager job strain on burnout, commitment and turnover intention: A cross-sectional study. Int. J. Nurs. Stud. 2015, 52, 1824-1833. [CrossRef]

16. Mutambudzi, M.; Javed, Z. Job strain as a risk factor for incident diabetes mellitus in middle and older age U.S. workers. J. Gerontol. Ser. B 2016, 71, 1089-1096. [CrossRef]

17. Madsen, I.E.H.; Nyberg, S.T.; Magnusson Hanson, L.L.; Ferrie, J.E.; Ahola, K.; Alfredsson, L.; Batty, G.; Bjorner, J.B.; Borritz, M.; Burr, H.; et al. Job strain as a risk factor for clinical depression: Systematic review and meta-analysis with additional individual participant data. Psychol. Med. 2017, 47, 1342-1356. [CrossRef] [PubMed]

18. Ferrario, M.M.; Veronesi, G.; Bertù, L.; Grassi, G.; Cesana, G. Job strain and the incidence of coronary heart diseases: Does the association differ among occupational classes? A contribution from a pooled analysis of Northern Italian cohorts. BMJ Open 2017, 7, e014119. [CrossRef] [PubMed]

19. Jun, D.; O'Leary, S.; McPhail, S.M.; Johnston, V. Job strain and psychological distress in office workers: The role of coping. Work 2019, 64, 55-65. [CrossRef] [PubMed] 
20. Clinchamps, M.; Auclair, C.; Prunet, D.; Pfabigan, D.; Lesage, F.-X.; Baker, J.S.; Parreira, L.; Mermillod, M.; Gerbaud, L.; Dutheil, F. Burnout among hospital non-healthcare staff: Influence of job demand-control-support, and effort-reward imbalance. J. Occup. Environ. Med. 2021, 63, e13-e20. [CrossRef] [PubMed]

21. Wall, T.D.; Jackson, P.R.; Mullarkey, S.; Parker, S.K. The demands-Control model of job strain: A more specific test. J. Occup. Organ. Psychol. 1996, 69, 153-166. [CrossRef]

22. Gadinger, M.C.; Fischer, J.E.; Schneider, S.; Terris, D.D.; Krückeberg, K.; Yamamoto, S.; Frank, G.; Kromm, W. Gender moderates the health-effects of job strain in managers. Int. Arch Occup. Environ. Health 2010, 83, 531-541. [CrossRef] [PubMed]

23. Rivera-Torres, P.; Araque-Padilla, R.A.; Montero-Simó, M.J. Job stress across gender: The importance of emotional and intellectual demands and social support in women. Int. J. Environ. Res. Public Health 2013, 10, 375-389. [CrossRef]

24. Bonsaksen, T.; Thørrisen, M.M.; Skogen, J.C.; Aas, R.W. Who reported having a high-strain job, low-strain job, active job and passive job? The WIRUS Screening study. PLOS ONE 2019, 14, e0227336. [CrossRef] [PubMed]

25. Bosma, H.; Peter, R.; Siegrist, J.; Marmot, M. Two alternative job stress models and the risk of coronary heart disease. Am. J. Public Health 1998, 88, 68-74. [CrossRef] [PubMed]

26. Wege, N.; Dragano, N.; Erbel, R.; Jockel, K.-H.; Moebus, S.; Stang, A.; Siegrist, J. When does work stress hurt? Testing the interaction with socioeconomic position in the Heinz Nixdorf Recall Study. J. Epidemiol. Community Health 2008, 62, 338-341. [CrossRef]

27. Backman, A.; Sjögren, K.; Lövheim, H.; Edvardsson, D. Job strain in nursing homes-Exploring the impact of leadership. J. Clin. Nurs. 2018, 27, 1552-1560. [CrossRef]

28. Kim, K.-W.; Cho, Y.-H. The Moderating Effect of Managerial Roles on Job Stress and Satisfaction by Employees' Employment Type. Int. J. Environ. Res. Public Health 2020, 17, 8259. [CrossRef]

29. Brett, J.M.; Stroh, L.K. Working 61 plus hours a week: Why do managers do it? J. Appl. Psychol. 2003, 88, 67-78. [CrossRef] [PubMed]

30. Dutheil, F.; Duclos, M.; Naughton, G.; Dewavrin, S.; Cornet, T.; Huguet, P.; Chatard, J.C.; Pereira, B. Wittyfit-live your work differently: Study protocol for a workplace-delivered health promotion. JMIR Res. Protoc. 2017, 6, e6267. [CrossRef]

31. Lesage, F.-X.; Berjot, S.; Deschamps, F. Clinical stress assessment using a visual analogue scale. Occup. Med. 2012, 62, 600-605. [CrossRef]

32. Dutheil, F.; Trousselard, M.; Perrier, C.; Lac, G.; Chamoux, A.; Duclos, M.; Naughton, G.; Mnatzaganian, G.; Schmidt, J. Urinary interleukin-8 is a biomarker of stress in emergency physicians, especially with advancing age-The JOBSTRESS* randomized trial. PLoS ONE 2013, 8, e71658. [CrossRef]

33. Dutheil, F.; Pereira, B.; Moustafa, F.; Naughton, G.; Lesage, F.-X.; Lambert, C. At-risk and intervention thresholds of occupational stress using a visual analogue scale. PLoS ONE 2017, 12, e0178948. [CrossRef]

34. Ben-Shachar, M.S.; Lüdecke, D.; Makowski, D. effectsize: Estimation of effect size indices and standardized parameters. J. Open Source Softw. 2020, 5, 2815. [CrossRef]

35. Funder, D.C.; Ozer, D.J. Evaluating effect size in psychological research: Sense and nonsense. Adv. Methods Pract. Psychol. Sci. 2019, 2, 156-168. [CrossRef]

36. R Core Team. R: A Language and Environment for Statistical Computing; R Foundation for Statistical Computing: Vienna, Austria, 2021; Available online: https://www.R-project.org/ (accessed on 14 May 2021).

37. Vanroelen, C.; Levecque, K.; Louckx, F. Differential exposure and differential vulnerability as counteracting forces linking the psychosocial work environment to socioeconomic health differences. J. Epidemiol. Community Health 2010, 64, 866-873. [CrossRef]

38. Niedhammer, I. Psychometric properties of the French version of the Karasek Job Content Questionnaire: A study of the scales of decision latitude, psychological demands, social support, and physical demands in the GAZEL cohort. Int. Arch. Occup. Environ. Health 2002, 75, 129-144. [CrossRef]

39. Trus, M.; Razbadauskas, A.; Doran, D.; Suominen, T. Work-related empowerment of nurse managers: A systematic review. Nurs. Health Sci. 2012, 14, 412-420. [CrossRef] [PubMed]

40. Cicolini, G.; Comparcini, D.; Simonetti, V. Workplace empowerment and nurses' job satisfaction: A systematic literature review. J. Nurs. Manag. 2014, 22, 855-871. [CrossRef] [PubMed]

41. Penconek, T.; Tate, K.; Bernardes, A.; Lee, S.; Micaroni, S.P.M.; Balsanelli, A.P.; de Moura, A.A.; Cummings, G.G. Determinants of nurse manager job satisfaction: A systematic review. Int. J. Nurs. Stud. 2021, 118, 103906. [CrossRef] [PubMed]

42. Padkapayeva, K.; Gilbert-Ouimet, M.; Bielecky, A.; Ibrahim, S.; Mustard, C.; Brisson, C.; Smith, P. Gender/sex differences in the relationship between psychosocial work exposures and work and life stress. Ann. Work. Expo. Health 2018, 62, 416-425. [CrossRef] [PubMed]

43. de Alves, M.G.M.; Hökerberg, Y.H.M.; Faerstein, E. Trends and diversity in the empirical use of Karasek's demand-control model (job strain): A systematic review. Revista Brasileira de Epidemiologia 2013, 16, 125-136. 